\title{
DEVELOPING COMMUNITY-BASED TOURISM: A STUDY IN WATER PARK WONOBOYO AND WONOBOYO MUSEUM, KLATEN OF CENTRAL JAVA
}

\author{
Wibawa Tri*, Widjanarko Hendro, Suratna, Utomo Humam Santosa \\ University of Pembangunan Nasional "Veteran" Yogyakarta, Indonesia \\ *E-mail: tri.wibawa@upnyk.ac.id
}

\begin{abstract}
Objective of this study is to develop community-based tourism in Water Park and Wonoboyo Museum in Klaten, Central Java using SWOT analysis. It used mix-method involving all stakeholders responsible for the tourist attractions. The findings showed that one of the methods to develop the tourist attractions was improving their managerial aspects. Private institutions (companies) may participate actively supporting these tourist attractions by allocating their CSR for their maintenance or development.
\end{abstract}

\section{KEY WORDS}

Community-based tourism, tourist management, stakeholder.

This study was conducted in Water Park and Wonoboyo Museum, two tourist attractions located in Wonoboyo village, Jogonalan, Klaten, Central Java. Both of them are located in one complex. Wonoboyo is famous for its springs and they are used to supply water to Water Park Wonoboyo, well-known tourist destination among the public. As an addition, this village was known for gold and other precious metal. They are housed in Wonoboyo Museum, making this place suitable for both education and recreational purpose. Water Park and Wonoboyo Museum are managed based on partnership between regional government and the local community. In other words, both can be classified as communitybased tourism. Similar to other tourist attractions, these recently developed destinations did not improve as quickly as expected, and academics should pay attention to this issue.

Due to the amount of funding and investment allocated for these tourist attractions, poor management will result in conflict among stakeholders. Scientific study is urgent in order to avoid dispute among the stakeholders. Based on the researchers' observations, the major obstacle the tourist attractions encountered is lack of human resources, individuals capable of running both destinations professionally. Academics help identifying and analyzing some issues that can hinder development of these tourist attractions and formulate a series of development plan.

Research problems were formulated after discussions between the researchers, government of Wonoboyo village and Kelompok Sadar Wisata Desa Wonoboyo, local initiative that actively promotes those tourist attractions. The discussions revealed three major issues Wonoboyo village encountered in tourism sector, namely social problem, managerial problem, and technology problem. These issues require at least three approaches to solve. Based on the researchers' analysis, the most important issue to tacke is partnership between the regional government, Kelompok Sadar Wisata, management of these tourist attractions and the locals. There has not been any clear distinction on how much responsibility/ authority each of these institutions has toward the Waterpark and the Museum. This may result in conflict among stakeholders. Social science allows researchers to develop a concept describing a harmonious pattern among the stakeholders, providing social value for all four. Management, as a discipline, allows researchers to develop a plan, apply and evaluate the plan, and eventually formulate a set of effective and efficient strategy. Technology allows management to develop a user-friendly service for visitors.

The aforementioned issue should be overcome as soon as possible since: (1) the village government has invested significant amount of investment in these tourist attractions. The fund was obtained from the government of Wonoboyo, Klaten, and Central Java. As an addition, the locals also donated their manpower and some building material. The 
management should ensure that the tourist attractions bring positive impacts to the local society; (2) Conflict may occur because of unclear description of authority and responsibility of institutions involved in managing these tourist destinations; (3) due to poor management and application of dated technology, some tourist attractions failed to visitors and as the consequence, investment allocated for its development goes to waste.

This study used both qualitative and quantitative methods (Mix Method) to provide a more extensive and in-depth funding. The data analysis method was Problem Solving Analysis in order to formulate an effective and applicable strategy. The researchers gathered both qualitative and quantitative data to identify issues management of both tourist destinations encountered and design accurate and implementive strategies.

This study aimed to formulate a set of strategies to develop community-based tourism in Wonoboyo village using SWOT Analysis. Furthermore, this study has both theoretical and practical significance. Theoretical contribution of this study was it contributes to the body of knowledge (case study), particularly provide some insight on how stakeholders run and manage community-based tourism in Wonoboyo. It is expected that this study reveals new information on community-based tourism and its management. Practical contribution of this study was that the findings of this study, the community-based strategy for Waterpark Wonoboyo and Wonoboyo Museum will provide higher income for the local community.

Not only did the findings of this study provide solutions for the stakeholders, but they also contributed to the state-of-the-art. The study reconstructed Freeman (1984)'s model of Stakeholder Theory. In this study, community-based tourism referred to a business entity. In general, tourist attraction is run by management (agent) and funding is provided by investors who look for financial benefit. On the other hand, in this study, management (agent) refers to both government and local community, and funding is provided by local community. These unique elements will provide new phenomenon in business and society.

\section{LITERATURE REVIEW}

Stakeholder Theory is the theory used as the basis for relationship among stakeholders in tourism management in Wonoboyo, while Porter (1980), and Hunger \& Wheelen (2001)'s SWOT Analysis becomes the basis for developing tourism development strategy.

Stakeholder theory emphasizes that organization is able to handle responsibility and remain in business if it is able to meet stakeholder's demand (Freeman, 1984). All stakeholders in tourism should get involved in evaluating the sector in order to makes ure tourist destination sustainability (Daub and Ergenzinger, 2005). These theories showed that tourist attraction that involves all stakeholders will grow and be sustainable.

UNEP (2005) stated that stakeholders in tourism sector comprises government, local community, entrepreneurs, and also visitors. In community-based tourism, public is represented by community group responsivle for running a tourist destination. Tourist destination brings positive impact to community group where it is located and can help promoting local custom and tradition. Thus, community members should get involved in planning, implementation, evaluation, and development of tourist attraction.

In this study, tourist attractions in Wonoboyo, run by the local government and the local community, have provided job vacancy for community members nearby, for example food vendor, parking attendant and Waterpark Wonoboyo and Wonoboyo Museum workers. In addition, the tourist attractions donate some percentages of their profit to Wonoboyo village. Relationship between these institutions should be identified clearly in order to create synergy and minimize conflict. Iniesta-Bonillo et al. (2016) and Utomo et al. (2018) showed that visitors will respond positively to tourist attraction that takes environment (nature, culture and local community) into consideration. Visitor is one of the elements that influence future of a tourist destination. Hence, in order to develop a sustainable tourist attraction, tourism management should acknowledge different interest, including that of local community.

Mathew and Sreejesh (2017) and Hussain et al. (2015) conducted tourism research from perspective of local community. These researches showed that local community plays pivotal role in making sure that tourist destination is sustainable. On the other hand, research 
on tourist destination from the perspective of an institution was conducted by Byrd (2007) and Kennett-Hensel (2009). Their studies showed that an institution responsible for management of tourist destination should have a clear responsibility and authority in order to avoid conflict. Butts and Sukhdeo-Singh (2010), Ya'nez and Sevilla (2010), and Sijlbing (2010) analyzed tourism management based on available facilities, including means of technology provided for visitors. Finally, Sa'nchez and Aramillo-Hurtado (2010), Cortez (2010), and Okech (2011) analyzed overall strategies for tourism.

The studies showed vital role of institution, local community, technology, and tourism strategy toward future of tourist destination. In this context, related stakeholders should work together in order to design a comperehensive solution to overcome the issue that waterpark and museum is currently dealing with.

According to Lawrence and Glueck (1998), a strategy is a unified, comprehensive and integrated plan that employs competive advantage of a company to overcome environmental challenge and making sure that objectives of the company can be achieved. In carrying out its functions and roles related to management of local tourism, local government and stakeholders (particularly the public) should develop various programs that aim to improve not only facilities and infrastructure, but also human resource and access.

SWOT (strengths, weaknesses, opportunities, threats) refers to a popular metheod of analysis describing strength, weakness, opportunity and threat that occur in planning. According to Freddy Rangkuti (2009), SWOT analysis is identifying various different factors in a systematic manner to formulate strategy for company. It is based on logic that maximizes strengths and opportunities, while minimizes weaknesses and threats at the stame time. Strategic decision-making gas always been related to developing mission, opportunity, strategy and policy of company. Hence, strategic planner refers to analysis of strength, weakness, opportunity and threats.

Porter (1980) revealed that strategic planner should create: 1) overall cost advantage; 2) differentiation; and 3) focus on buyers, product line segments and particular market (one related to geography). In order to create competitive advantage, tourist development strategy should involve the three. Competition among tourist attractions is inevitable, however synergy and cooperative work will create advantage. Hunger and Wheelen (2001) stated that strategic planning comprises four elements, namely: a). identifying strategic issues organization encounters; b). developing alternatives by taking generic strategy and its variations into account; $\mathrm{c}$ ). evaluating every alternative; and d). selecting the most suitable strategy among available alternatives. This study adopted Hunger and Wheelen (2001)'s strategic planning process.

\section{METHODS OF RESEARCH}

The study used mixed method (qualitative and quantitative) to obtain a thorough and in-depth analysis from various perspectives considering partners faced different issues. The data were primary and secondary data. The primary data were obtained from some informants, namely Head of Wonoboyo village, Waterpark Wonoboyo and Wonoboyo Museum management, MSMEs located around the tourist attraction, local famers who depend upon the springs in Wonoboyo, religious figures, and village elders. On the other hand, secondary data were obtained from management of the waterpark and museum. The data collection methods were open-ended questionnaire, interview, Focus Group Discussion, and Documentation. Triangulation, cross-checking data from the local government, tourist management, and local community directly affected by the waterpark and museum was conducted to ensure validity of the data. The data analysis method was qualitative and descriptive analysis.

\section{RESULTS AND DISCUSSION}

Triangulation, validity testing method, was conducted to confirm information from local government (village and region), Badan Usaha Milik Desa (village-owned enterprise), 
Kelompok Sadar Wisata, the public figures and the elders. Based on the triangulation, the data were valid. Open and close-ended questionnaires were distributed to Water Park Wonoboyo and Wonoboyo Museum visitors. The questionnaire revealed that according to the respondents, the tourist attractions needed: (1) cleaner swimming pool; (2) trees or shades to protect against sun or rain; (3) gazebo and benches; (4) more exhibits in the museum; (5) trained tour guide; (7) food stalls; (8) announcement board; (9) trained lifeguard in the swimming pools; (10) swimming class; (11) trash bin; (12) green open space; and (13) a more effective promotion.

The researchers interviewed the Head and Secretary of Wonoboyo village, Wonoboyo village-owned enterprise managers, kelompok sadar wisata, the public figures and some visitors. Result of the interview is elaborated as follows:

1. Waterpark Wonoboyo and Wonoboyo Museum have a lot of potentials since the central government plans to build toll road exit gate near the tourist attractions in a short time;

2. The local society supports development of the tourist attraction;

3. The tourist attractions do not reduce water supply for either farmers or local community;

4. Waterpark Wonoboyo management should improve water circulation technology for their swimming pools;

5. Waterpark Wonoboyo and Wonoboyo Museum have positive influence towards economic sector of the local community;

6. Though quite little, the tourist attractions have positive impact towards Wonoboyo village income;

7. Schools (from kindergarten to senior high schools) are interested in visiting the tourist attractions, particularly the museum.

Conducted in November 2019 in the waterpark and museum, FGD involved government of Wonoboyo village, management staffs of the waterpark and museum, villageowned enterprise management, and public figures and village elders. Result of the FGD is summarized as follow:

1. All stakeholders have agreed on developing Waterpark Wonoboyo and Wonoboyo Museum further;

2. They have agreed on running the tourist attractions based on principles of community-based tourism (run professionally by the local community;

3. Major issue management of the waterpark and museum encountered is lack of professionalism or managerial skills, and as the result, training and consultation are needed;

4. Management cannot rely on admission because these tourist attractions are relatively new;

5. Lack of funding results in poor maintenance and lack of infrastructure and facilities for visitors and thus, management should invite other institutions to help funding the tourist attractions (as an example CSR);

6. Wonoboyo Museum has very little collections at the moment since management have difficulty to contact the central government.

Documentation aimed to capture real condition of Waterpark Wonoboyo and Wonoboyo Museum. Observation to the field revealed the following information: (1) the tourist attractions are strategically located on the side of the street and surrounded by both residential area and ricefield; (2) ground water becomes source of water for swimming pool in the waterpark; (3) Waterpark Wonoboyo needs water circulation system; (4) very few visitors visited the tourist attaractions; (5) management of the tourist attractions should plant more trees to protect visitors from heat; (6) management should provide more trash bins; (7) management should provide gazebos or seatings for visitors to rest; (8) Waterpark Wonoboyo management should improve quality of water in the swimming pools; (9) management should build ticket counter; (10) management should build or add changing room; (11) lifeguards should wear uniform; (12) management should hire parking attendant; (13) management should provide announcement board; (14) Wonoboyo Museum is in a 
good condition; (15) the museum should increase their collections; (16) management of the museum should reconsider their lay-out.

\section{DISCUSSION OF RESULTS}

Waterpark Wonoboyo and Wooboyo Museum is run by the local community and funding for their operating activities are obtained from both village government and the local community. Government of Wonoboyo, Jogonalan Klaten is responsible for both tourist attractions. The local government appointed village-owned entreprise staffs and Kelompok Sadar Wisata Desa Wonoboyo to run the waterpark and museum. Their organization comprises Wonoboyo village government, Wonoboyo village-owned enterprise staffs, and local community members. Due to poor management system, the tourist attractions lacked infrastructure and facilities.

The following aspects can be used for planning and implementation of the tourist attractions:

- Attractions. Visitors visit Water Park Wonoboyo to exercise and have family gathering. On the other hand, they visit Wonoboyo Museum to learn about some artifacts (gold houseware and jewelry found near the museum). These distinguish the tourist attractions from others;

- Ammenities. Waterpark Wonoboyo has swimming pools for children and adult. However, management should improve quality of water in the swimming pools as unsanitary swimming pool may cause various diseases. Other facilities are parking lot, waiting area and toilets. Based on the data collection, the visitors wished for praying room, announcement board, cafeteria, and other shops where they can buy snacks or swimming equipment;

- Accessibility. These tourist attractions are located 1 kilometer from Yogyakarta-Solo road. Access road to the waterpark and museum is paved road. In near future, they are located very close to Solo-Yogyakarta toll road exit gate;

- Image. The tourist attractions have yet to leave a lasting image among visitors due to lack of facilities and poorly maintained swimming pool. Management has yet been able to use the swimming pool to attract more visitors. Thus, to attract more visitors, the management should improve better facilities and provide excellent service.

- Price. The waterpark and museum offer affordable admission fee. As the consequence, management barely have enough fund for operating activities. Without a professional management system, Waterpark Wonoboyo and Wonoboyo Museum will not become a sustainable tourist attraction.

Based on social perspective, participation of local community in running the tourist attractions is a strategic choice. It results in commitment and participation, including decision to visit these tourist attractions. This type of management can also become a pilot-project to develop partnership between local government and local community.

Management of the waterpark and museum have yet to make use of technology for water circulation system, designing facilities for visitors (ergonomic seating, pool and its railings), or designing a suitable lay-out for the museum.

Even though very little, these tourist attractions have positive impact toward economic sector of Wonoboyo. They become new source of income for the local government. The local society can also make money out of the waterpark and museum. When the local government conducted carnival or cultural performance, the local society usually sells food or beverages or becomes parking attendants.

Social benefit of the tourist attraction is coherence between community members and between community member and local govenrment. This coherence is a capital to create a more prosperous and developed community. The local community can also make use of the tourist attractions to improve creativity, for instance cultural and art performance (puppet show, jathilan, hadroh, karawitan, and music performance). 
Based on the analysis, some weaknesses of the tourist attractions are:

- Management. Tourism sector requires a huge investment. Waterpark Wonoboyo and Wonoboyo Museum have not been run professionally yet. Therefore, management should conduct training on professional tourism management;

- Watepark Wonoboyo does not have a standardized water circulation system. Management has yet to conduct any laboratory testing to identify whether their swimming pool is safe for swimming;

- The tourist attraction management cannot depend on admission fee for operating activities, and as the result, the local government allocated some funding for the tourist attractions. This funding may go to waste due to poor management system.

Some threats for Waterpark Wonoboyo and Wonoboyo Museum are as follow:

- Other institutions are building swimming pools making use of a lot of springs in Wonoboyo;

- Solo-Yogyakarta toll road may cause detour. Consequently, it will take some visitors longer time to get to the tourist attractions;

- Admission fees are affordable, even free. Management should establish an admission fee, one that matches facilities visitors get from the tourist attractions.

Strength of Waterpark Wonoboyo and Wonoboyo Museum are:

- Management use ground water for the swimming pools and thus, water bill can be minimized;

- The tourist attractions were built on the local government land. As the result, rent is fairly low;

- Social capital in the form of cohesion between local community members and between local community members and local community members is strong;

- The museum is in a good condition, and the swimming pool is ready to use;

- The tourist attractions are accessible.

Opportunities to develop these tourist attractions are:

- Solo-Yogyakarta toll road makes the tourist attractions more accessible;

- Higher village fund means more funding to develop these tourist attractions;

- Wonoboyo is where some factories and warehouses are located. The museum and waterpark management can invite these companies to participate in the tourist attractions through CSR.

Development strategy focuses on visitors, increasing their satisfaction, revisit intention and willingness to recommend the museum and waterpark to other people. Based on the SWOT analysis, the development strategies are as follow:

- Incerase managerial skills of Waterpark Wonoboyo and Wonoboyo Museum management;

- Develop water circulation system;

- Improve quality of service in Wonoboyo Museum;

- Build some facilities (e.g, praying room, waiting area, green open space, and cafeteria);

- Invite companies located in Wonoboyo and nearby areas to allocate their CSR to develop Waterpark Wonoboyo and Wonoboyo Museum.

\section{CONCLUSION}

Based on the discussions, conclusions are as follow:

- Waterpark Wonoboyo and Wonoboyo Museum have a lot of potentials and bring positive impact toward village fund and local community members;

- Waterpark Wonoboyo and Wonoboyo Museum management system needs a lot of improvement;

- Waterpark Wonoboyo management should run laboratory test to ensure that their swimming pools are safe for visitors. 
The findings of this study function as recommendations for Waterpark Wonoboyo and Wonoboyo Museum management. The management should increase their professionalism and work together with professionals including universities. They can use CSR to develop the tourist attraction. As an addition, the management should maintain facilities for visitors.

Limitation of this study is its scooe. It was conducted only in one tourist complex in Klaten, Central Java. Furthermore, this study is a cross-sectional, instead of longitudinal. The researchers could not access several data (financial report) and consequently, had to rely on respondents for financial information.

To bridge gap of this study, future research should conduct a study identifying quality of water in the swimming pool and making sure that the swimming pools are safe for visitors. Future researchers should also conduct study on role of community members in development of community-based tourism. Finally, they can also conduct research on economic impact of Wonoboyo Water Park and Wonoboyo Museum.

\section{REFERENCES}

1. Butts, T. and Tameca Sukhdeo-Singh (2010). Sustainable tourism as a tool for conservation and protection of the Amazon rainforest in Guyana? Worldwide Hospitality and Tourism Themes Vol. 2 No. 2, 2010 pp. 173-185.

2. Byrd, Erick T. (2007). Stakeholders in Sustainable Tourism Development and their Roles: Applying Stakeholder Theory to Sustainable Tourism Development. Tourism Review, Vol 62, No 2/2007.

3. Cortez, S. L. (2010). Strategies for the development of sustainable tourism in the Amazon rainforest of Bolivia. Worldwide Hospitality and Tourism Themes Vol. 2 No. 2, 2010 pp. 136-143.

4. Daub, C. H., and Ergenzinger, R. (2005). Enabling sustainable management through a newmulti-disciplinary concept of customer satisfaction. European Journal of Marketing, 39(9-10), 998-1012.

5. Freeman, R. E. (1984). Strategic management: A stakeholder approach. Marshfield: Pitman Publishing Inc.

6. Hunger, J. David and Thomas L Wheelen (2001). Manajemen Strategis, Yogyakarta: Andi.

7. Hussain, K., Faizan Ali, Neethiahnanthan Ari Ragavan, and Parikshat Singh Manhas (2015). Sustainable tourism and resulting resident satisfaction at Jammu and Kashmir, India. Worldwide Hospitality and Tourism Themes Vol. 7 No. 5, 2015.

8. Iniesta-Bonillo, M.A., Raquel Sánchez-Fernández, and David Jiménez-Castillo (2016). Sustainability, value, and satisfaction:Model testing and cross-validation in tourist destinations. Journal of Business Research 69 (2016) 5002-5007.

9. Kennett-Hensel, P. A., Julie Z. Sneath and Paul J. Hensel (2009). Developing sustainable tourism: managers' assessment of Jamaica's ten-year master plan. International Journal Of Culture, Tourism And Hospitality Research. Vol. 4 NO. 2 2010, pp. 143-155.

10. Lawrence R.J. and Glueck, W.F. (1998). Manajemen Strategis dan Kebijakan Perusahaan Edisi ketiga. Penerbit Erlangga, Jakarta.

11. Mathew, P.V. and Sreejesh S. (2017). Impact of responsible tourism on destination sustainability and quality of life of community in tourism destinations. Journal of Hospitality and Tourism Management 31 (2017) 83-89.

12. Okech, Roselyne N. (2011). Promoting sustainable festival events tourism: a case study of Lamu Kenya. Worldwide Hospitality and Tourism Themes Vol. 3 No. 3, 2011 pp. 193202.

13. Porter, Michael E. (1980). Strategi Bersaing. Jakarta: Erlangga.

14. Rangkuti, Freddy (2002). Analisis SWOT Teknik Membedah Kasus Bisnis, Jakarta: Gramedia Pustaka Tama.

15. Sa'nchez, C.I. and Maria Eugenia Jaramillo-Hurtado (2010). Policies for enhancing sustainability and competitiveness in tourism in Colombia. Worldwide Hospitality and Tourism Themes Vol. 2 No. 2, 2010 pp. 153-162. 
16. Sijlbing, Harrold A. (2010). Does sustainable tourism offer solutions for the protection of the Amazon rainforest in Suriname? Worldwide Hospitality and Tourism Themes Vol. 2 No. 2, 2010 pp. 192-200.

17. UNEP (2005). Forging links between protected areas and the tourism sector: How tourism can benefit conservation. UNEP Division of Technology, Industry and Economics (DTIE). Production and Consumption Unit. Tourism Programme. Paris, France. http://www.unep.fr/shared/publications/pdf/DTIx0591xPA-ForgingLinks.pdf.

18. Utomo, H.S., Kusumawati, A., Suharyono, Sunarti (2018). Y Generation Participation In Recommending Sustainable Tourism: A Study Of Asian Travelers In Bali Island. RJOAS, 12(84), December 2018.

19. Ya'nez, E. and Eduardo Sevilla (2010). A sustainable tourism approach to the protection of the Amazon rainforest. The case of Peru. Worldwide Hospitality and Tourism Themes Vol. 2 No. 2, 2010 pp. 186-191. 